\title{
GENERAL CONTRIBUTIONS
}

Book reviews

\section{The philosophy, politics and economics of information. Archie L Dick.} Pretoria: UNISA Press, 2002, 184p.

ISBN I 868882020 (sb)

Price: In South Africa: RI29; Other countries in Africa: RI48,20

This book offers a fresh, new look at information, and this approach opens the door to focus on the contemporary debate on information philosophy and the political economy of information. The book is divided into four segments (which the author refers to as an information circuit) namely, the representation of information, its production, regulation, and the consumption of information. As the author puts it, 'The articulation between these elements of the information circuit allows the convergence of conceptual and material dimensions that typify the difficulties of information discourse. In other words, the bipolar or twofold nature of information requires a simultaneous recognition of its "softer" meaning-related side and its "harder" physical attributes. The information circuit also opens up for discussion the idea of information industries and their economic and social roles, as well as the idea of information's role in philosophical and political contexts' (p.I5I).

Under the philosophy of information, the author covers the following themes:

- representation of information, where a hermeneutical and sociological approach is followed,

- knowledge, which is defined from an epistemological perspective,

- ethical dilemmas pertaining to the use of information,

- the sociological aspects of information, which cover themes such as globalisation, informatisation and post-modernity. The producing of information covers a variety of socio-political issues pertaining to the production and distribution of information. Specific attention is given to the political economy of information production in South Africa. Other relevant topics include: ownership of information, the global information economy and the mapping of information industries. The South African information industries are specifically mentioned.

The section dealing with the regulation and deregulation of information distribution focuses on information policy issues at the national and international levels. Specific attention is given to the role of the state and free market mechanisms that can influence the regulation of information flow. Information policy issues in South Africa are also addressed.

The book ends with a conclusion where the main themes are summarised and the aim of the book is explained again.

In summary, the book is a timely publication in South Africa. It is well written and is a suitable text for those scholars who are interested in the contemporary debate on the political economy of information in South Africa. However, one has to bear in mind that this book is only an introduction to these themes and thus does not cover them in great detail. Another disadvantage is the fact that most of the sources used are older than 1999.

The author, Professor A Dick, is currently a professor in the Department of Information Science at the University of Pretoria, South Africa.

Professor J] Britz, School of Information Technology, University of Pretoria, South Africa.

Tel.: +27 (I2) 4202962

e-mail: britzh@postino.up.ac.za

\section{E-Serials: Publishers, libraries, users and standards}

Edited by Wayne Jones. $2^{\text {nd }}$ ed. New York: Haworth Information Press, 2003. 294p. ISBN 07890 I 2294 (hbk), ISBN 0 789012308 (pbk)

This second edition retains most of the original chapters of the first, which was published in 1998; but the information has been brought up to date and new topics introduced. The editor acknowledges that there are bound to be gaps in the subject coverage, but to cover absolutely everything about electronic serials would produce a volume the size of a 'James Michener novel'. 